\title{
The Dynamics of Winter Wheat Production and Analysis of the Main Affecting Factors in the Regions of the RA in 1991-2020
}

\author{
V.S. Aleksanyan, G.H. Keshishyan \\ Armenian National Agrarian University \\ S.N. Shirokov, I.R. Trushkina \\ Saint-Petersburg State Agrarian University \\ vardan.aleqsanyan@gmail.com, keshishyan@inbox.ru, shirokovspbgau@mail.ru, auriairina@mail.ru
}

\section{A R T I C L E I N F O}

Keywords:

gross yield,

sown area,

yield per hectare,

main development tendency,

statistical index analysis

\begin{abstract}
A B S T R A C T
The main goal of the current research is to study development tendencies of winter wheat production in the period of 1991-2020 and to examine the effect of the changes in cropland areas and yield capacity per hectare on the gross yield of winter wheat in separate periods. In 1991-2005, the gross yield demonstrated extensive (quantitative) growth, and in 2006-2016, it was characterized by intensive (qualitative) growth. In 2017-2020, the yield capacity per hectare decreased almost in all marzes of the RA. As a result, the gross yield of winter wheat annually decreased by 13.54 thousand tons in the mentioned subperiod.
\end{abstract}

\section{Introduction}

Cereal production is one of the key directions of food security in the Republic of Armenia. In the mentioned context it is very important to develop the level of grain production infrastructures, properly implement agrotechnological measures and to continuously improve the developing mechanisms of the sector. In the sector of grain/cereal crop production winter wheat has a significant role, since its share in the gross yield of total cereal crop production is rather high. In the RA, throughout 19912020, the self-sufficiency rate of wheat didn't increase above $54 \%$. Only in 2016, the self-sufficiency rate of wheat was $53.2 \%$, which was mainly due to the yield increase per hectare. The low level of self-sufficiency rate is related to the gross yield of winter wheat, which, in its turn, is directly estimated upon the yield per hectare.

Due to the economic and political situation throughout the years of independence in the Republic of Armenia, almost all economic sectors were developing with constantly changing tendencies.

The aim of this research is to study the main development tendency of winter wheat production indices for the period of 1991-2020, and to disclose the impact of cropland sizes and yield capacity level on the gross yield per the studied subperiods. 


\section{Materials and methods}

The development tendency of the winter wheat's gross yield has been analyzed via the trend modeling for individual periods and the significant shifts taken place in the entire period have been disclosed. The tendency has been presented by the linear trend:

$$
\widehat{y}_{t}=a+b_{1} t
$$

where $\hat{y}_{t}$ is the calculated value of studied indicators by the linear trend, $t$ is the time factor $(t=1 ; 2 ; \ldots n), a, b_{1}$ are the parameters, $b_{1}$ describes the absolute growth of the studied phenomena (Eliseeva, 2014). The whole studied period was divided into three analytical subperiods based on the notable variation of time series indicators of gross yield for winter wheat, such as the absolute differences, growth rate, etc. The separate periods included the following years: 1991-2005, 2006-2016, 2017-2020, and the analyses were conducted per marzes of the RA. The separation was done, since the main characteristics of formed trends for each subperiod were significantly different.

For disclosing the effect of the changes in harvest areas and yield amount per hectare on the dynamics of winter wheat's gross yield production, the analyses were done through the index analysis methods. Statistical index analysis method allows to disclose individual effects of qualitative and quantitative factors on the dynamic of studied phenomena (Gromiko, 2005).

The aggregate index and the absolute growth of gross yield are presented as follows:

$$
\begin{gathered}
I_{B C}=\frac{B C_{1}}{B C_{0}}=\frac{\sum \Pi_{1} Y_{1}}{\sum \Pi_{0} Y_{0}}, \\
\Delta_{B C}=\mathrm{BC}_{1}-\mathrm{BC}_{0}=\sum \Pi_{1} \mathrm{Y}_{1}-\sum \Pi_{0} \mathrm{Y}_{0} .
\end{gathered}
$$

The aggregate index of the yield per hectare and the absolute growth of gross yield due to change of the yield per hectare are presented as follows:

$$
\begin{gathered}
I_{Y}=\frac{\sum \Pi_{1} Y_{1}}{\sum \Pi_{1} Y_{0}}, \\
\Delta_{Y}=\sum \Pi_{1} Y_{1}-\sum \Pi_{1} Y_{0} .
\end{gathered}
$$

The aggregate index of the sown area and the absolute growth of gross yield due to change of the sown area are presented as follow:

$$
\begin{gathered}
I_{\Pi}=\frac{\sum \Pi_{1} Y_{1}}{\sum \Pi_{1} Y_{0}}, \\
\Delta_{I I}=\sum \Pi_{1} \mathrm{Y}_{0}-\sum \Pi_{0} \mathrm{Y}_{0} .
\end{gathered}
$$

$B C_{1}$ and $B C_{0}$ are the gross yields in comparable periods, $\Pi_{1}$ and $\Pi_{0}$ are the sown areas in comparable periods, $Y_{1}$ and $Y_{0}$ are the yields per hectare in comparable periods (Hakobyan, 2004). The statistical index analysis of winter wheat's gross yield allows to underline the intensive or extensive ways of its growth. The time series of gross yield, sown areas and yield per hectare in the RA are demonstrated in Figures 1, 2, 3.

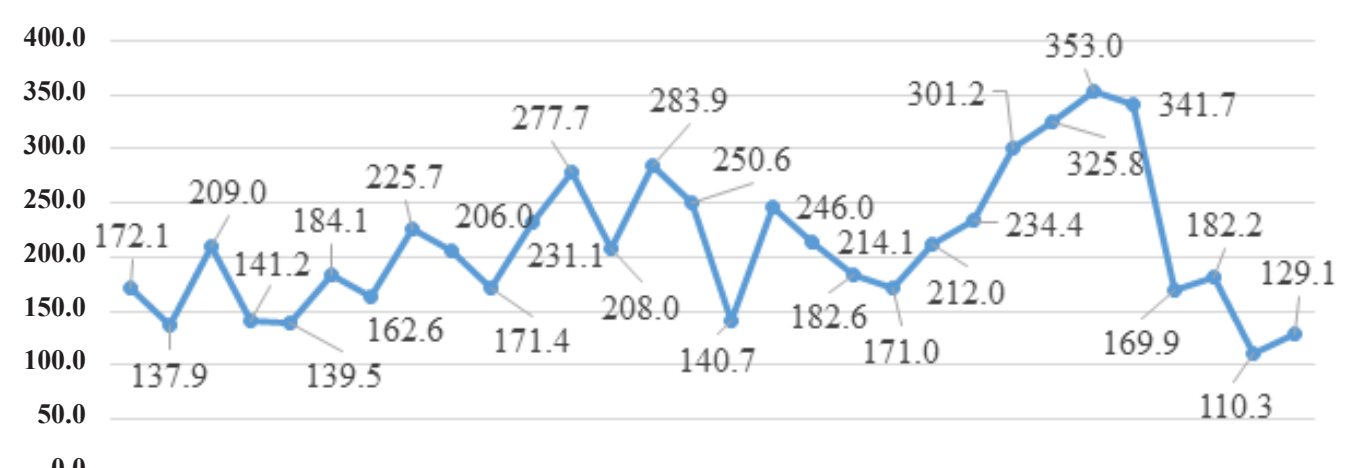

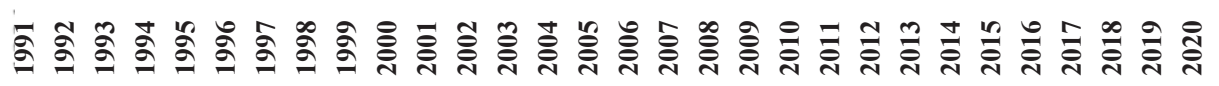

Figure 1. The gross yield of winter wheat in the RA for 1991-2020, 1000 tons ("Agriculture in the Republic of Armenia, 1991-2005" Statistical Compendium - 2001, 2006", "Sown areas of agricultural crops, croplands of perennial plants, gross yield and average yield capacity" Statistical Bulletin, NSS of the RA, 2006-2018, "Sown areas of agricultural crops, croplands of perennial plants, gross yield and average yield capacity" Statistical Bulletin, NSC of the RA, 2019-2021). 


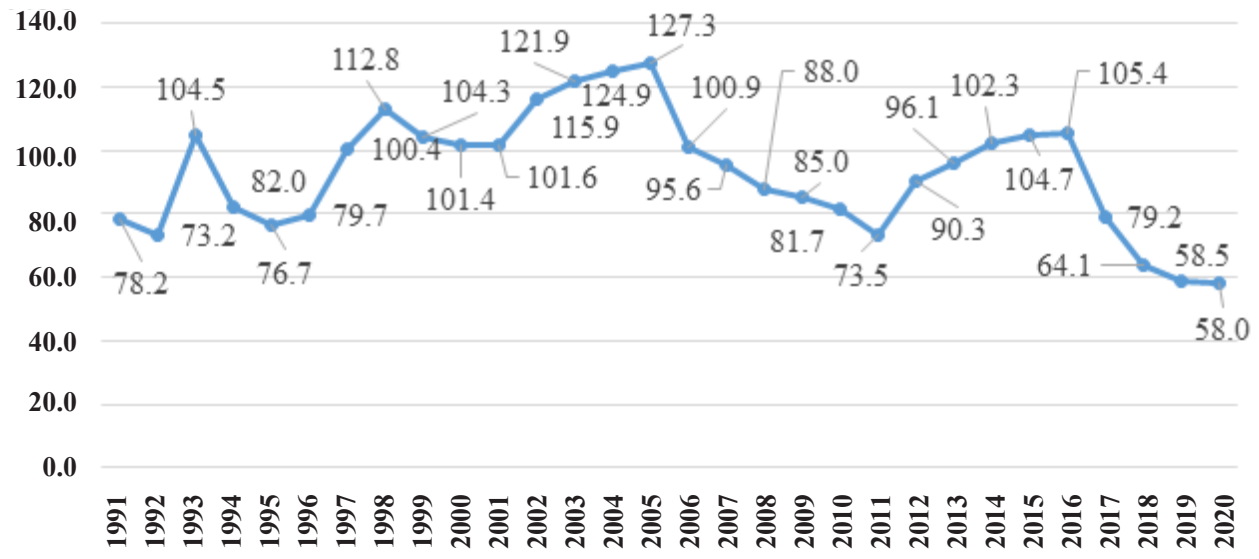

Figure 2. The sown areas of winter wheat in the RA for 1991-2020, 1000 ha ("Agriculture in the Republic of Armenia, 1991-2005" Statistical Compendium - 2001, 2006 "Sown areas of agricultural crops, croplands of perennial plants, gross yield and average yield capacity" Statistical Bulletin, NSS of the RA, 2006-2018, "Sown areas of agricultural crops, croplands of perennial plants, gross yield and average yield capacity" Statistical Bulletin, NSC of the RA, 2019-2021).

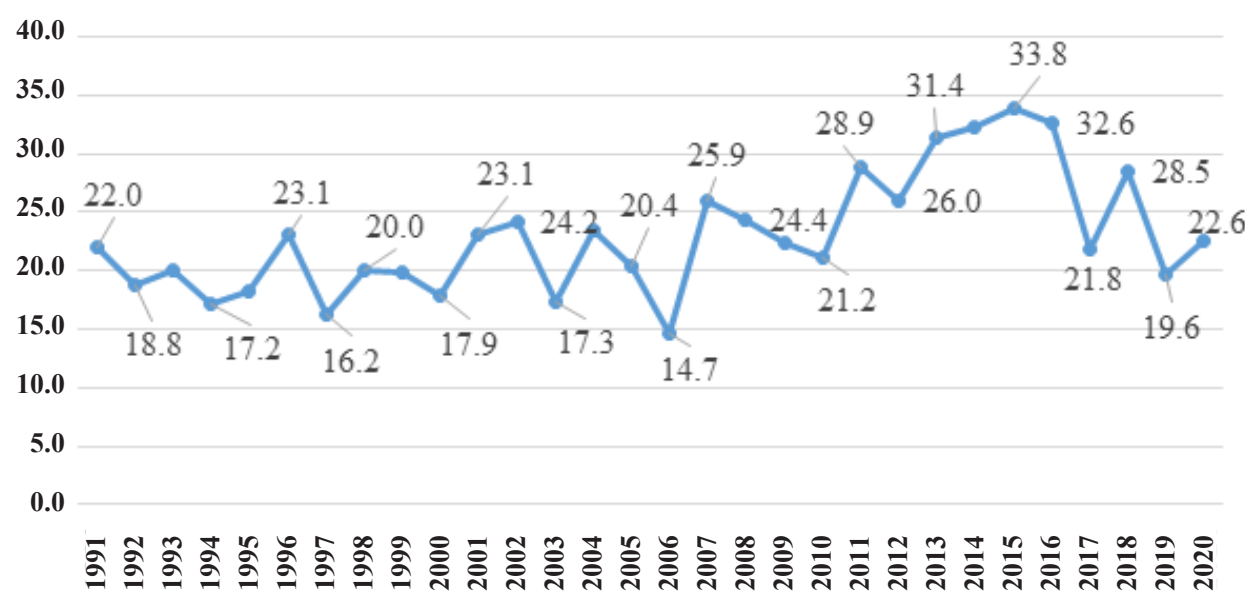

Figure 3. The yield of winter wheat per hectare in the RA, 1991-2020, centner ("Agriculture in the Republic of Armenia, 19912005 " Statistical Compendium - 2001, 2006 "Sown areas of agricultural crops, croplands of perennial plants, gross yield and average yield capacity" Statistical Bulletin, NSS of the RA, 2006-2018, "Sown areas of agricultural crops, croplands of perennial plants, gross yield and average yield capacity” Statistical Bulletin, NSC of the RA, 2019-2021).

\section{Results and discussions}

The results of trend modeling of gross yield for winter wheat are introduced in Table 1.

Table 1. The trend modeling results of winter wheat for separate periods in the RA*

\section{1-2005}

$$
\widehat{y}_{t}=135.5+8.07 t
$$$$
R^{2}=0.576, \quad F=17.6 \text {, }
$$

$$
t_{b 1}=4.2
$$

\section{6-2016}

$$
\begin{gathered}
\hat{y}_{t}=134.7+18.8 t \\
R^{2}=0.733, \quad F=24.7, \\
t_{b 1}=4.9
\end{gathered}
$$

2017-2020

$$
\begin{gathered}
\hat{y}_{t}=196.4-19.4 t \\
R^{2}=0.551, \quad F=2.45, \\
t_{b 1}=1.5
\end{gathered}
$$

*Composed by the authors. 
Table 2. The average sown areas, gross yield and yield per hectare for winter wheat in the marzes of the RA per separate periods within 1991-2020*

\begin{tabular}{|c|c|c|c|c|c|c|c|c|c|}
\hline \multirow[b]{2}{*}{$\begin{array}{l}\text { Marzes/ } \\
\text { Regions }\end{array}$} & \multicolumn{3}{|c|}{ 1991-2005 } & \multicolumn{3}{|c|}{ 2006-2016 } & \multicolumn{3}{|c|}{$2017-2020$} \\
\hline & $\begin{array}{c}\text { Sown } \\
\text { area, } \\
1000 \text { ha }\end{array}$ & $\begin{array}{l}\text { Gross } \\
\text { yield, } \\
1000 \text { tons }\end{array}$ & $\begin{array}{l}\text { Yield per } \\
\text { hectare, } \\
\text { centner }\end{array}$ & $\begin{array}{l}\text { Sown } \\
\text { area, } \\
1000 \text { ha }\end{array}$ & $\begin{array}{c}\text { Gross } \\
\text { yield, } \\
1000 \text { tons }\end{array}$ & $\begin{array}{l}\text { Yield per } \\
\text { hectare, } \\
\text { centner }\end{array}$ & $\begin{array}{c}\text { Sown } \\
\text { area, } \\
1000 \text { ha }\end{array}$ & $\begin{array}{c}\text { Gross } \\
\text { yield, } \\
1000 \text { tons }\end{array}$ & $\begin{array}{l}\text { Yield per } \\
\text { hectare, } \\
\text { centner }\end{array}$ \\
\hline Aragatsotn & 6.76 & 10.3 & 15.2 & 9.85 & 26.0 & 26.4 & 6.12 & 12.3 & 20.1 \\
\hline Ararat & 9.20 & 31.2 & 33.9 & 4.89 & 19.3 & 39.3 & 2.32 & 9.0 & 38.6 \\
\hline Armavir & 14.19 & 47.9 & 33.7 & 5.96 & 19.9 & 33.3 & 3.24 & 13.0 & 40.1 \\
\hline Gegharkunik & 11.13 & 16.0 & 14.3 & 15.98 & 44.7 & 28 & 11.16 & 19.9 & 17.8 \\
\hline Lori & 9.63 & 17.2 & 17.9 & 8.25 & 21.1 & 25.5 & 7.96 & 23.6 & 29.7 \\
\hline Kotayk & 7.57 & 10.2 & 13.5 & 6.35 & 12.3 & 19.4 & 4.41 & 9.1 & 20.6 \\
\hline Shirak & 20.19 & 36.3 & 18.0 & 21.93 & 61.1 & 27.8 & 16.95 & 39.2 & 23.2 \\
\hline Syunik & 12.42 & 17.3 & 13.9 & 12.07 & 30.3 & 23.2 & 8.39 & 16.1 & 19.1 \\
\hline Vayots Dzor & 2.17 & 2.7 & 12.2 & 1.07 & 2.3 & 21.7 & 0.39 & 0.8 & 20.0 \\
\hline Tavush & 6.22 & 9.3 & 15.0 & 4.33 & 10.1 & 23.3 & 2.8 & 5.1 & 18.0 \\
\hline Yerevan & 0.29 & 0.9 & 31.0 & 0.14 & 0.4 & 32.5 & $\mathrm{x}$ & $\mathrm{x}$ & $\mathrm{x}$ \\
\hline RA & 100.32 & 199.2 & 19.9 & 93.05 & 247.5 & 26.6 & 64.94 & 148.0 & 22.8 \\
\hline
\end{tabular}

Table 3. The results of index analysis of winter wheat gross yield in the marzes of RA for the period of 1991-2005*

\begin{tabular}{|c|c|c|c|c|c|c|}
\hline \multirow{3}{*}{ Marzes/Regions } & \multicolumn{2}{|c|}{$\begin{array}{c}\text { The surplus (reduction) } \\
\text { of gross yield }\end{array}$} & \multicolumn{4}{|c|}{ Due to changes in } \\
\hline & \multirow{2}{*}{1000 tons } & \multirow{2}{*}{$\%$} & \multicolumn{2}{|c|}{ sown area } & \multicolumn{2}{|c|}{ yield per hectare } \\
\hline & & & 1000 tons & $\%$ & 1000 tons & $\%$ \\
\hline Aragatsotn & 0.381 & 102.2 & -0.027 & 99.8 & 0.409 & 102.4 \\
\hline Ararat & 2.204 & 109.2 & 2.333 & 109.9 & -0.309 & 99.8 \\
\hline Armavir & 2.269 & 107.3 & 4.272 & 110.8 & -2.003 & 96.9 \\
\hline Gegharkunik & 0.709 & 102.7 & -0.027 & 99.9 & 0.736 & 102.8 \\
\hline Lori & 0.366 & 102.1 & 1.004 & 104.7 & -0.638 & 97.5 \\
\hline Kotayk & 0.393 & 102.7 & 1.128 & 106.1 & -0.735 & 96.8 \\
\hline Shirak & -0.667 & 98.2 & 1.422 & 102.9 & -2.089 & 95.4 \\
\hline Syunik & 0.272 & 101.2 & 0.572 & 102.4 & -0.299 & 98.9 \\
\hline VayotsDzor & -0.027 & 99.1 & -0.076 & 97.1 & 0.049 & 102.0 \\
\hline Tavush & -0.129 & 98.8 & 0.143 & 101.1 & -0.272 & 97.7 \\
\hline Yerevan & 0.026 & 105.6 & 0.024 & 105.4 & 0.001 & 100.2 \\
\hline RA & 6.261 & 102.9 & 7.715 & 103.5 & -1.455 & 99.5 \\
\hline
\end{tabular}


According to the main characteristics of trend modeling, the development tendency of winter wheat's gross yield significantly varied between the individual periods. In 1991-2005, the gross yield of winter wheat annually increased by 8.07 thousand tons, in 2006-2016 it annually increased by 18.8 thousand tons. In 2006-2016, the increasing tendency of winter wheat gross yield was much higher than that of observed for the period of 1991-2005; it was mainly due to the growth of yield amount per hectare (index analysis is introduced in Tables 3,4).

In 2017-2020, the gross yield of winter wheat annually decreased by 19.4 thousand tons due to the decrease of yield per hectare and sown areas (Table 5).

Table 4. The results of index analysis of winter wheat gross yield in the marzes of the RA for the period of 2006-2016*

\begin{tabular}{|c|c|c|c|c|c|c|}
\hline \multirow{3}{*}{ Marzes/Regions } & \multicolumn{2}{|c|}{$\begin{array}{c}\text { The surplus (reduction) } \\
\text { of gross yield }\end{array}$} & \multicolumn{4}{|c|}{ Due to changes of } \\
\hline & \multirow{2}{*}{1000 tons } & \multirow{2}{*}{$\%$} & \multicolumn{2}{|c|}{ Sown area } & \multicolumn{2}{|c|}{ Yield per hectare } \\
\hline & & & 1000 tons & $\%$ & 1000 tons & $\%$ \\
\hline Aragatsotn & 3.033 & 113.1 & 0.609 & 104.1 & 2.424 & 108.7 \\
\hline Ararat & -0.077 & 99.7 & -0.892 & 96.0 & 0.816 & 103.9 \\
\hline Armavir & -1.477 & 94.0 & -1.984 & 90.8 & 0.507 & 103.5 \\
\hline Gegharkunik & 2.363 & 109.9 & 0.276 & 101.7 & 2.087 & 108.1 \\
\hline Lori & 2.549 & 113.2 & 0.204 & 101.8 & 2.346 & 111.9 \\
\hline Kotayk & 1.329 & 113.6 & -0.059 & 98.8 & 1.388 & 114.9 \\
\hline Shirak & 6.949 & 114.1 & 0.749 & 102.6 & 6.200 & 111.2 \\
\hline Syunik & 3.797 & 117.7 & 0.24 & 102.3 & 3.557 & 114.9 \\
\hline Vayots Dzor & 0.366 & 120.3 & 0.018 & 102.3 & 0.348 & 117.6 \\
\hline Tavush & 1.265 & 117.6 & 0.139 & 103.8 & 1.125 & 113.3 \\
\hline Yerevan & -0.009 & 98.1 & -0.025 & 93.5 & 0.016 & 104.9 \\
\hline RA & 20.053 & 109.3 & 1.309 & 100.9 & 18.743 & 108.9 \\
\hline
\end{tabular}

Table 5. The results of index analysis of winter wheat gross yield in the marzes of the RA for the period of 2017-2020*

\begin{tabular}{|c|c|c|c|c|c|c|}
\hline \multirow{3}{*}{ Marzes/Regions } & \multicolumn{2}{|c|}{$\begin{array}{c}\text { The surplus (reduction) } \\
\text { of gross yield }\end{array}$} & \multicolumn{4}{|c|}{ Due to changes of } \\
\hline & \multirow{2}{*}{1000 tons } & \multirow{2}{*}{$\%$} & \multicolumn{2}{|c|}{ Sown area } & \multicolumn{2}{|c|}{ Yield per hectare } \\
\hline & & & 1000 tons & $\%$ & 1000 tons & $\%$ \\
\hline Aragatsotn & -2.416 & 85.3 & -3.439 & 77.1 & 1.023 & 110.6 \\
\hline Ararat & -2.066 & 80.7 & -2.142 & 79.8 & 0.076 & 101.1 \\
\hline Armavir & -0.533 & 96.3 & -0.821 & 94.3 & 0.287 & 1.022 \\
\hline Gegharkunik & -0.761 & 96.2 & -1.424 & 92.7 & 0.663 & 1.038 \\
\hline Lori & 0.253 & 101.2 & 0.305 & 101.4 & -0.052 & 99.8 \\
\hline Kotayk & -1.097 & 88.4 & -0.836 & 91.5 & -0.261 & 96.7 \\
\hline Shirak & -3.747 & 90.4 & -4.237 & 88.9 & 0.49 & 101.6 \\
\hline Syunik & -1.479 & 91.3 & -0.997 & 94.3 & -0.482 & 96.8 \\
\hline VayotsDzor & -0.282 & 66.5 & -0.241 & 73.5 & -0.041 & 90.5 \\
\hline Tavush & -1.541 & 71.0 & -0.696 & 89.2 & -0.845 & 79.6 \\
\hline RA & -13.473 & 91.3 & -14.998 & 90.2 & 1.524 & 101.2 \\
\hline
\end{tabular}


As shown in Table 2, in 1991-2005 the maximum gross yield was recorded in Armavir region, which amounted to 478.53 thousand tons, and in the following period the maximum gross yield of winter wheat was observed in Shirak region, i.e., in 2006-2016 it reached 610.59 thousand tons, while in 2017-2020 it fell down to 392.42 thousand tons.

As the results of analysis indicate, in the period of 19912005, in the marzes of Ararat, Armavir, Lori, Kotayk and Syunik, the gross yield surplus of winter wheat was only due to the expansion of sown areas, which was associated with the decrease of yield capacity per hectare. The gross yield of winter wheat decreased in the Shirak (by 0.667 thousand tons), Vayots Dzor (by 0.027 thousand tons) and Tavush (by 0.129 thousand tons) regions, which is fully related to the decrease of yield capacity per hectare.

In the mentioned period the sown areas of winter wheat decreased, but the gross yield increased in the Aragatsotn and Ghegharkunik regions. In the Aragatsotn region, the gross yield increased by 0.381 thousand tons due to per hectare yield increase by 0.409 thousand tons, and in the Ghegharkunik region the gross yield increased by 0.709 thousand tons due to per hectare yield increase by 0.736 thousand tons (Table 3 ).

In 2006-2016 the gross yield of winter wheat decreased in the Ararat, Armavir regions and in Yerevan city mainly due to the decrease of sown areas (Table 4). The gross yield reduction of winter wheat is a positive shift for the agricultural sector in these marzes. During this period, in the abovementioned regions intensive agricultural branches, such as horticulture, viticulture and vegetable growing, were developed. In the other regions the gross yield of winter wheat is characterized by intensive growth. The gross yield surplus of winter wheat in Aragatsotn, Gegharkunik, Lori, Kotayk, Shirak, Syunik and Vayots Dzor regions was due to the increase of yield capacity per hectare. These mentioned regions are specialized in cereal crops, particularly in wheat production, where wheat production indices have been rather improved. It is no coincidence, that in this period the self-sufficiency rate of wheat reached the maximum level against the other studied years (in 2016 the self-sufficiency rate of wheat was $53.2 \%$ ) (Statistical Bulletin, SC of the RA, 2021).

In 2017-2020, almost in all marzes of the RA, the gross yield of winter wheat decreased, again due to the decrease of yield capacity per hectare (Table 5). Due to the reduction of sown area the gross yield of winter wheat decreased in the Aragatsotn, Ararat, Armavir, Gegharkunik and Shirak marzes. In the marzes of Syunik, Vayots Dzor and Tavush the gross yield decreased due to the reduction of both the sown areas and per hectare yield capacity.

\section{Conclusion}

The aim of the research is to disclose the development tendency of winter wheat production, as well as the effect of cropland areas and yield capacity dynamics on the production indices within the entire period of 1991-2020 years. Related to the significant discrepancies in the main indicators of the gross yield dynamics, the studied period was divided into three subperiods: 1991-2005, 2006-2016 and 2017-2020.

In 1991-2005, the difficult socioeconomic situation of the country made the farmers expand the croplands of winter wheat to ensure food security, as a result of which the annual gross yield surplus of winter wheat made 6.26 thousand tons. This period can be considered as the period of qualitative decline of wheat production.

In the next period of 2006-2016, the gross yield of winter wheat significantly increased, especially in such specialized marzes as Shirak, Gegharkunik, Kotayk, Lori and Syunik. The growth of gross yield was related to the yield increase per hectare by more than 1.5 times. In this period the main indicators of winter wheat production were qualitatively improved.

In 2017-2020, the gross yield of winter wheat annually decreased by 19.42 thousand tons mainly due to the decrease of sown areas and, in individual regions, to the decline of the yield capacity per hectare. These adverse changes resulted in the decrease of wheat self-sufficiency ratio by $54.4 \%$.

Despite the fact that RA is a grain importing country, the promotion of yield capacity increase should be viewed as one of the key objectives of the agricultural strategic plan. The continuous increase of the yield capacity in the specialized regions of the republic will enable to ensure the development of cereal crop infrastructures and improvement of the relevant mechanisms.

\section{References}

1. Agriculture in the Republic of Armenia, 1991-2005, Statistical Compendium, NSS of the RA, Yerevan 2001, - 157 p., Yerevan 2006, - 167 p. (in Armenian).

2. Eliseeva, I.I. (2014). Econometrics: Textbook for Master Students. - M: Yurayt Publishing House, - 453 p.

3. Food Safety and Poverty January - December 2020, Statistical Bulletin, SC of RA, Yerevan 2021, - 110 p. (in Armenian). 
4. Gromiko, G.L. (2005). Theory of Statistics: Textbook / 2-nd Edition, M.: INFRA - M, - 476 p. (in Russian).

5. Hakobyan, K.H. (2004). Socio-Economic Statistics, Unit 2, - Yerevan, - 104 p. (in Armenian).

6. Sown Areas of Agricultural Crops, Croplands of Perennial Crops, Gross Yield and Average Yield Capacity. Statistical Bulletin, NSC of RA, Yerevan - 2019, - 76 p., Yerevan - 2020, - 76 p., Yerevan - 2021, - 76 p. (in Armenian).
7. Sown Areas of Agricultural Crops, Croplands of Perennial Crops, Gross Yield and Average Yield Capacity. Statistical Bulletin, NSS of RA, Yerevan - 2006, - 37 p., Yerevan - 2007, - 36 p., Yerevan - 2008 - 38 p., Yerevan - 2009, - 37 p., Yerevan - 2010, - 38 p., Yerevan - 2011, -37 p., Yerevan - 2012, - 38 p., Yerevan - 2013, - 37 p., Yerevan-2014, - 38 p., Yerevan - 2015, - 38 p., Yerevan - 2016, - 40 p., Yerevan 2017, - 75 p., Yerevan - 2018, - 76 p. (in Armenian).

The research was carried out with the financial support of the Russian Foundation for Basic Research and the Science Committee of the $R A$ within the framework of the scientific project No. 20-510-05020 20 (No. 20RF-054). 